\section{Mineral Nutrition, Growth, and Germination of Antirrhinum majus L. (Snapdragon) when Produced Under Increasingly Saline Conditions}

\author{
Christy T. Carter ${ }^{1,2}$ and Catharine M. Grieve \\ USDA-ARS, U.S. Salinity Laboratory, 450 West Big Springs Road, Riverside, \\ CA 92507
}

Additional index words. cut-flowers, salinity, seed germination, wastewater

\begin{abstract}
The conservation of quality water is of special concern, especially in California, as the need for quality water increases with a growing population. Reusing saline wastewaters to irrigate salt-tolerant floral crops provides a viable option to produce quality marketable cut flowers while conserving the highest quality water for other purposes. A completely randomized design with three replications was used to investigate the effects of five salinity treatments $\left[2.5\right.$ (control) $\left., 5,8,11,14 \mathrm{dS} \cdot \mathrm{m}^{-1}\right]$ and two water ionic compositions: concentrations of Colorado River water (CCRW) and dilutions of sea water (SWD), on the mineral uptake, germination, growth, and quality of two cultivars of Antirrhinum majus ('Monaco Rose' and 'Apollo Cinnamon'). Seeds of both cultivars were sown in 30 greenhouse sand tanks. Leaves were collected 2 months after planting and analyzed for concentrations of $\mathrm{Ca}^{2+}, \mathrm{Mg}^{2+}, \mathrm{Na}^{+}, \mathrm{Cl}^{-}, \mathrm{K}^{+}$, total $\mathrm{P}$, and total $\mathrm{S}$. As salinity increased, $\mathrm{Ca}^{2+}, \mathrm{Mg}^{2+}, \mathrm{Na}^{+}, \mathrm{Cl}^{-}$, and total $\mathrm{S}$ increased in plant tissues, whereas $\mathrm{K}^{+}$ and total $P$ decreased in plant tissues for both cultivars in both irrigation solutions. Leaf nutrient composition was related to the interactions of ions within the substrate solutions and their ability to compete for uptake at the site of root membranes. Phenotypic measurements, made when plants were harvested, showed only slight decreases as salinity increased. A $2 \times 5$ factorial design was used to determine the effects of water ionic composition and salinity on the germination of seeds. Four replicate Petri dishes each with 25 seeds were exposed to constant temperature $\left(20^{\circ} \mathrm{C}\right)$ and an 8 -h dark : 16-h light photoperiod to promote germination. Germination was checked daily for $16 \mathrm{~d}$. Snapdragons can be produced from seed when exposed to salinities up to $14 \mathrm{dS} \cdot \mathrm{m}^{-1}$ using both SWD and CCRW ionic solutions for irrigation because germination remained at $92 \%$ or greater. Quality of the flowering stems was rated according to standards developed by the Society of American Florists. Marketable stems of both cultivars were produced in all treatments. Overall, quality of stems produced with saline waters ranging from 2.5 to $11 \mathrm{dS} \cdot \mathrm{m}^{-1}$ was very high ("special"). Irrigation with more saline water $\left(14 \mathrm{dS} \cdot \mathrm{m}^{-1}\right)$ resulted in a slight reduction in quality and stems were rated as "fancy" depending on the cultivar. Both cut flower cultivars can be produced for commercial use under saline conditions up to at least $14 \mathrm{dS} \cdot \mathrm{m}^{-1}$.
\end{abstract}

The conservation of water has become an increasingly important practice, especially in western states and throughout the state of California where competition for quality

Received for publication 27 Nov. 2007. Accepted for publication 5 Feb. 2008.

This investigation was funded by a 2002 CAL-FED grant administered by the California Department of Water Resources, Project Manager, Debra Gonzalez. We thank Donald A. Layfield for conducting plant and water mineral analyses. Phyllis Nash and Scott Lesch provided statistical assistance. Doug Diaz and Stephen Wegulo screened for plant pests. We thank Kathy Kim, Jaime Hiraoka, and Alvin Fong for assistance with data collection.

Mention of company names or products is for the benefit of the reader and does not imply endorsement, guarantee, or preferential treatment by the USDA or its agents.

${ }^{1}$ Current address: Tennessee Tech University, Department of Biology, 122 Pennebaker Hall, Box 5063, Cookeville, TN 38506.

${ }^{2}$ To whom reprint requests should be addressed; e-mail ctcarter@tntech.edu and Grieve, 1999; Greenway and Munns, 1980). In most cases, exposure to salt stress results in injury or death resulting from salinityinduced nutritional disorders (Grattan and Grieve, 1999). Yet many floral crops, including statice, cockscomb, stock, and sunflower, have shown varying levels of tolerance to salinity (Carter and Grieve, 2006; Carter et al., 2005a, 2005b; Grieve et al., 2006).

Most floriculture operations in California are located along the coast where growers irrigate their crops with groundwater. Recently, however, many growers have recognized that sea water intrusion is occurring and is contaminating their source of high-quality water. One of their concerns is how crops will respond to increases in salinity caused by infiltration of sodium chloride, the primary salt in sea water, into the groundwater (Carter et al., 2005a). Another consideration is the release of effluents that contain high amounts of nutrients and salts by nursery and greenhouse operators into local streams, aquifers, and rivers. Many growers have responded by recycling discharge effluents for reuse in their own operations or in nearby agricultural systems (Carter et al., 2005a). A third consideration is that producers are finding it more lucrative to sell their coastal property as the value of their real estate increases and relocate further inland to areas such as the Imperial and Coachella Valley (ICV). Some growers are actually expanding operations in the ICV. Agricultural crops in this region are irrigated with water from the Colorado River, which contains salts and nutrients arising from agricultural runoff from upriver agricultural operations throughout the Colorado River watershed. Magnesium and calcium sulfate-based salts are found in this soil and irrigation water in addition to sodium chloride (Carter et al., 2005a). Salinity of the water from the Colorado River watershed varies depending on the sampling location. In the Imperial Valley, salinity has been measured at $1.48 \mathrm{dS} \cdot \mathrm{m}^{-1}$ and in Yuma, AZ, salinity has been recorded at $1.38 \mathrm{dS} \cdot \mathrm{m}^{-1}$ (Ayers and Westcot, 1985). Growers find it important to understand how their crops will respond to different combinations and types of salts.

Typically, plants at earlier stages of development do not always demonstrate the same levels of tolerance as their mature counterparts (Waisel, 1989). The seed and seedling stages of development are particularly vulnerable to increases in salinity because plants in these stages have not yet developed the physiological mechanisms to tolerate increasing salinity concentrations (Adam, 1990). In fact, seeds of halophytes have been reported to show their highest percentage of germination under nonsaline conditions (Carter et al., 2005b; Ungar, 1991). However, Carter et al. (2005b) found that seeds of Limonium perezii demonstrated the highest germination under moderately saline conditions. Understanding the salt tolerance limits at the germination stage of development allows growers to produce their crops from seed using saline wastewaters if 
the seeds demonstrate high germination percentages under increasing saline conditions.

Antirrhinum majus L. (Scrophulariaceae) (snapdragon) is a perennial native to the Mediterranean region. However, it is treated as an annual when grown in gardens and as a cut flower (Gleason and Cronquist, 1991). Its irregular-shaped flowers occur in terminal racemes and are variously colored. Monk and Peterson (1961) showed that snapdragons ('Super Majestic') could survive when irrigated with solutions having salt concentrations up to $60 \mathrm{meq} \cdot \mathrm{L}$ of sodium and calcium chloride, but not up to $120 \mathrm{meq} \cdot \mathrm{L}$. Given its ability to tolerate saline irrigation water and its economic importance to the cut flower industry, $A$. majus was selected as a potential cut flower crop for saline environments. 'Monaco Rose' and 'Apollo Cinnamon' were selected based on their growing conditions and flowering times and are designated as Group 2 and 3 varieties, respectively (Corr and Laughner, 1998).

The goals of this investigation were to: 1) determine whether marketable cut flowers, as determined by stem length, of two A. majus varieties could be produced when grown in two different increasingly saline irrigation water compositions; 2) assess the mineral nutrition of two varieties of $A$. majus when exposed to increasingly saline irrigation water; 3) assess changes in morphology for each variety as salinity increased in irrigation waters differing in ion compositions; and 4) determine the germinability of seeds from two varieties of $A$. majus when exposed to increasingly saline irrigation water.

\section{Materials and Methods}

Production in greenhouse conditions. A completely randomized design was used to test for the effects of saline irrigation waters differing in ionic composition and salinity $\left(2.5,5,8,11,14 \mathrm{dS} \cdot \mathrm{m}^{-1}\right)$ on the growth and production of two varieties of Antirrhinum majus ('Apollo Cinnamon' and 'Monaco Rose') under greenhouse conditions. Water ionic composition 1 (CCRW) was typical of saline tailwaters present in the inland valleys of southern California and essentially represents concentrations of Colorado River water. Composition 2 (SWD) mimicked coastal well waters contaminated with seawater, which are essentially dilutions of sea water modified to achieve a $1: 1 \mathrm{Ca}: \mathrm{Mg}$ ratio necessary for adequate plant nutrition (Grattan and Grieve, 1999). In both cases, salt solutions for the study were prepared to simulate the compositions of these wastewaters and from predictions based on appropriated simulations of what the long-term composition of the water would be on further concentrations by plant-water extraction and evaporation (Suarez and Simunek, 1997). Seeds for each variety, purchased from the PanAmerican Seed Company (West Chicago, IL), were sown in 30 greenhouse sand tanks $(1.2 \times 0.6 \times 0.5 \mathrm{~m}$ deep $)$. One-half of each tank was planted with 'Apollo Cinnamon' and the other half with 'Monaco Rose' on 22 Sept. 2003 at the U.S. Salinity Laboratory in Riverside, CA. Each tank contained six rows with 10 wells. Rows were spaced at $17.5 \mathrm{~cm}$ and wells had 5-cm spacings. Each well was planted with two seeds and then thinned to one seedling per well after cotyledon emergence on 29 Sept. resulting in 30 plants per variety per tank.

Sand tanks contained washed river sand with an average bulk density of $1.54 \mathrm{Mg} \cdot \mathrm{m}^{-3}$. Volumetric water content was $0.34 \mathrm{~m}^{3} \cdot \mathrm{m}^{-3}$ at saturation and $0.1 \mathrm{~m}^{3} \cdot \mathrm{m}^{-3}$ after water drained from the tanks by gravity into $765-\mathrm{L}$ subsurface reservoirs. Tanks were flood-irrigated twice daily for $\approx 5$ min until seedlings emerged at which time irrigation was reduced to once daily during the warmest time of day. One of either two water ionic compositions made with city of Riverside municipal water was used for irrigation. The base nutrient solution consisted of (in mmol): $2.3 \mathrm{Ca}^{2+}, 3.0$ $\mathrm{Mg}^{2+}, 10.5 \mathrm{Na}^{+}, 5.0 \mathrm{~K}^{+}, 3.3 \mathrm{SO}_{4}{ }^{2-}, 13.3 \mathrm{Cl}^{-}$, $5.0 \mathrm{NO}_{3}^{-}$, and $0.34 \mathrm{KH}_{2} \mathrm{PO}_{4}$. Micronutrients (in $\mu \mathrm{mol}$ ) based on Hoagland's micronutrient solution included 100.0 Fe as sodium ferric diethylenetriamine pentacetate (NaFeDTPA), $46.0 \mathrm{H}_{3} \mathrm{BO}_{3}, 10.0 \mathrm{MnSO}_{4}, 0.8 \mathrm{ZnSO}_{4}, 0.4$ $\mathrm{CuSO}_{4}$, and $0.2 \mathrm{H}_{2} \mathrm{MoO}_{4}$. The base nutrient solution served as a control with an electrical conductivity $\left(\mathrm{EC}_{\mathrm{i}}\right)$ of $2.5 \mathrm{dS} \cdot \mathrm{m}^{-1}$ and their calculations accounted for the mineral concentrations present in the municipal water. Irrigation water $\mathrm{pH}$ in each reservoir was maintained at 5.5 using $1 \mathrm{~N} \mathrm{H}_{2} \mathrm{SO}_{4}$ to provide for optimal growing conditions for snapdragons. Sulfuric acid was used to adjust $\mathrm{pH}$ instead of ammonia because ammonia can have negative growth effects on snapdragons (Corr and Laughner, 1998; Dole and Wilkins, 1999). To account for any water lost to evapotranspiration, water volume in subsurface reservoirs was automatically replenished daily to maintain target $\mathrm{EC}$ and mineral concentrations.

Salinity treatments for both water ionic compositions were applied beginning 14 Oct. 2003 after the expansion of second leaves. In addition to the control, target $\mathrm{EC}_{\mathrm{i}}$ levels for both water compositions were $5,8,11$, and 14 $\mathrm{dS} \cdot \mathrm{m}^{-1}$ (Table 1). To avoid effects of osmotic shock, salinizing salts were added to reservoirs in daily increments so that the highest salinity $\left(14 \mathrm{dS} \cdot \mathrm{m}^{-1}\right)$ was attained on the fourth day. An Orion model 126 conductivity meter (Orion Research, Beverly, MA) was used weekly to confirm target treatment water EC levels in reservoirs. Ion concentrations $\left(\mathrm{Ca}^{2+}, \mathrm{Mg}^{2+}, \mathrm{Na}^{+}, \mathrm{K}^{+}\right.$, total $\mathrm{P}$, total $\mathrm{S}, \mathrm{Cl}^{-}$, and $\mathrm{NO}_{3}^{-}$) of irrigation waters from the reservoirs were analyzed weekly using inductively coupled plasma optical emission spectrometry (ICPOES). Coulometricamperometric titration was used to analyze chloride. On 13 Nov. 2003, an additional 425 $\mathrm{mL}$ of micronutrients, $150 \mathrm{~g} \mathrm{KNO}_{3}$, and $22 \mathrm{~g}$ $\mathrm{KH}_{2} \mathrm{PO}_{4}$ were added to each reservoir to meet nutrient requirements of plants. Plant height measurements were recorded weekly on 10 marked plants for each cultivar in each tank beginning 23 Oct. 2003.

Greenhouse air temperature and relative humidity were recorded hourly at a single point above the plant canopy from 22 Sept. 2003 to 28 Feb. 2004. Day air temperatures ranged from 6.8 to $42.2{ }^{\circ} \mathrm{C}$ with a mean of $23.6{ }^{\circ} \mathrm{C}$, whereas night air temperatures ranged from 5.6 to $28.1^{\circ} \mathrm{C}$ with a mean of $15.2^{\circ} \mathrm{C}$. Relative humidity readings for the daytime ranged from $40.7 \%$ to $47.4 \%$ with a mean of $45.3 \%$, whereas nighttime relative humidity readings ranged from $42.7 \%$ to $47.5 \%$ with a mean of $45.6 \%$.

Plant mineral analyses. On 24 Nov. 2003, shoots of plants were harvested to provide at least $1.0 \mathrm{~g}$ of dried plant material per variety per tank. Only vegetative material was collected because plants had not yet begun to flower. Fresh plant material was weighed, triple-washed in deionized water, and dried in a forced air oven at $70{ }^{\circ} \mathrm{C}$ for $72 \mathrm{~h}$. Dried plant material was weighed and ground to pass a 60-mesh screen. ICPOES, including a nitricperchloric acid digest, was used to determine $\mathrm{Ca}^{2+}, \mathrm{Mg}^{2+}, \mathrm{Na}^{+}, \mathrm{K}^{+}$, total $\mathrm{S}$, and total $\mathrm{P}$. Coulometric-amperometric titration from unfiltered nitric-acetic acid extracts was used for $\mathrm{Cl}^{-}$.

Plants were harvested individually beginning in Jan. 2004 when one-half to two-thirds of the flowers were open (Armitage, 1993). Morphometric data were recorded on the 10 marked plants from which height measurements were recorded weekly. These data included: the number of days to flower, shoot height (soil line to plant tip), shoot height nonfloral (soil line to lowest floret), stem

Table 1. Target concentrations (m) of saline water solutions used to irrigate Antirrhinum majus at increasing salinity $\left(\mathrm{dS} \cdot \mathrm{m}^{-1}\right)$.

\begin{tabular}{|c|c|c|c|c|c|c|c|}
\hline \multirow{2}{*}{$\begin{array}{l}\mathrm{EC} \\
\left(\mathrm{dS} \cdot \mathrm{m}^{-1}\right)\end{array}$} & $\mathrm{Ca}^{2+}$ & $\mathrm{Mg}^{2+}$ & $\mathrm{Na}^{+}$ & $\mathrm{K}^{+}$ & $\mathrm{SO}_{4}{ }^{2-}$ & $\mathrm{Cl}^{-}$ & $\mathrm{NO}_{3}$ \\
\hline & \multicolumn{7}{|c|}{ 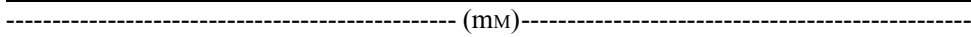 } \\
\hline \multicolumn{8}{|c|}{ Concentrations of Colorado River Water } \\
\hline 2.5 & 2.3 & 3.0 & 10.5 & 5.0 & 3.3 & 13.25 & 5.0 \\
\hline 5 & 4.8 & 7.7 & 26.6 & 5.0 & 8.3 & 34.8 & 5.0 \\
\hline 8 & 7.6 & 12.7 & 43.6 & 5.0 & 13.6 & 57.2 & 5.0 \\
\hline 11 & 10.0 & 17.9 & 61 & 5.0 & 19.1 & 80.2 & 5.0 \\
\hline 14 & 13.5 & 23.5 & 81 & 5.0 & 25.3 & 107 & 5.0 \\
\hline \multicolumn{8}{|c|}{ Sea water dilutions } \\
\hline 2.5 & 2.5 & 1.2 & 14.5 & 5.0 & 0.4 & 18.3 & 5.0 \\
\hline 5 & 2.8 & 2.8 & 34.0 & 5.0 & 1.1 & 43.1 & 5.0 \\
\hline 8 & 4.6 & 4.6 & 55.1 & 5.0 & 1.8 & 69.8 & 5.0 \\
\hline 11 & 6.9 & 6.9 & 77.1 & 5.0 & 2.5 & 97.7 & 5.0 \\
\hline 14 & 8.3 & 8.3 & 98.7 & 5.0 & 3.3 & 126.0 & 5.0 \\
\hline
\end{tabular}

$\mathrm{EC}=$ electrical conductivity. 
basal diameter (at soil line), cut flower stem diameter (measured $40 \mathrm{~cm}$ below lowest floret), shoot weight (soil line to plant tip), cut flower weight (included $40 \mathrm{~cm}$ of stem below lowest floret with the lowest $15 \mathrm{~cm}$ of leaves removed from this portion), and dry weight.

The rating scale for snapdragon developed by the Society of American Florists was used to determine marketable quality (Dole and Wilkins, 1999). Grades include: "special" (flower stem weight 71 to $113 \mathrm{~g}$, minimum stem length $91 \mathrm{~cm}$ ); "fancy" (flower stem weight 43 to $79 \mathrm{~g}$, minimum stem length $76 \mathrm{~cm}$ ); "extra" (flower stem weight 29 to 42 $\mathrm{g}$, minimum stem length $61 \mathrm{~cm}$ ); and "first" (flower stem weight 14 to $28 \mathrm{~g}$, minimum stem length $46 \mathrm{~cm}$ ).

Germination in growth chamber conditions. A $2 \times 5$ factorial design was used to determine the effects of water ionic composition and salinity on germination of snapdragon seeds under growth chamber conditions. Again, each variety was treated separately. For each treatment combination, 25 seeds were placed into each of four replicate $50 \mathrm{~mm} \times$ 9-mm Gelman (Paul Gelman Sciences Corp., Ann Arbor, MI) plastic Petri dishes each containing two layers of Whatman \#5 (Whatman, Florham Park, NJ) filter paper and $2 \mathrm{~mL}$ of treatment water. Treatment waters were collected from the subsurface reservoirs and were the same water treatments used to irrigate the crops in the greenhouse (Table 1). Petri dishes were completely randomized and placed in a growth chamber programmed at a constant temperature of $20 \pm 1{ }^{\circ} \mathrm{C}$. A constant temperature was selected to promote germination for both varieties (Corr and Laughner, 1998). Full light in the growth chamber ranged from 41 to $47 \mu \mathrm{mol} \cdot \mathrm{m}^{-2} \cdot \mathrm{s}^{-1}$ when measured using a quantum sensor attached to a LI-COR 6400 Portable Photosynthesis System (Lincoln, NE). Photoperiod was programmed as follows to simulate natural light conditions: $10 \mathrm{~h}$ full light, $1 \mathrm{~h}$ $75 \%$ (of full light), $1 \mathrm{~h} 50 \%, 1 \mathrm{~h} 25 \%, 8 \mathrm{~h}$ dark, $1 \mathrm{~h} 25 \%, 1 \mathrm{~h} 50 \%$, and $1 \mathrm{~h} 75 \%$. Relative humidity was not controlled but was maintained $\approx 50 \%$. Two additional controls were also implemented for each variety. Four replicates of 25 seeds were treated with tap water because it was the base used to make the water ionic solutions, and an additional four replicate Petri dishes contained deionized water. Seeds in Petri dishes were checked daily for $16 \mathrm{~d}$ for germination and the number of seeds having germinated was recorded. Recording of germination was stopped after $16 \mathrm{~d}$ when no new seeds in any dish germinated for 3 consecutive days (days 14 to 16 ). Radicle emergence was the criterion used to assess germination.

Statistical analyses. A two-way fixedeffects general linear model (GLM) analysis of variance (ANOVA) was used to determine the effects of water composition (CCRW or SWD) and salinity on mineral concentration and growth parameters for each variety. When differences were found, a Tukey post hoc multiple comparison procedure was used to assess significant differences between individual means. Analyses were conducted on nontransformed data. ANOVA was performed for each mineral based on replicates of tank values. Tank means for plant growth measurement data were based on a sample of 10 marked plants per tank for each parameter measured. Some missing data points occurred for all minerals because some plants in tanks at the highest salinities did not have an adequate amount of fresh leaf material to produce $1 \mathrm{~g}$ of dry material for analyses 2 months after sowing. Therefore, a type III sum of squares was performed. Although no missing data points occurred for the growth data, a type III sum of squares was also used for analysis. An $\alpha$ level of 0.05 with double precision was selected for the ANOVA and Tukey post hoc tests. Statistical analyses were performed with SAS Release 8.2 using proc GLM (SAS Institute, 2001).

A two-way fixed-effects GLM ANOVA with a type I sum of squares was used to determine the effects of water composition (CCRW or SWD) and increasing salinity on seed germination. Again, each variety was treated separately. When differences were found, a Bonferroni post hoc procedure was used to determine significant differences between individual means. Analyses were performed on arsine square root transformed data. Means and SEs for each treatment were converted to percentages for graphical presentation. An $\alpha$ level of 0.05 with double precision was used for the ANOVA and Bonferroni post hoc tests. Analyses were performed in Number Cruncher Statistical Systems (NCSS) 2004 (Hintze, 2006).

\section{Results}

Mineral analysis. Concentrations of $\mathrm{Ca}^{2+}$, $\mathrm{Mg}^{2+}, \mathrm{Na}^{+}$, and $\mathrm{Cl}^{-}$in plant tissues increased and $\mathrm{K}^{+}$and total $\mathrm{P}$ decreased with the increase of salinity for both cultivars irrigated with both water compositions. Whereas total $\mathrm{S}$ concentrations increased in plant tissues for plants irrigated with CCRW, total S concentrations showed only slight increases in tissues of plants irrigated with SWD (Figs. 1-2).

Water ionic composition and salinity had significant two-way interactions for mineral concentrations of $\mathrm{Ca}^{2+}(F=4.23 ; P<0.05)$, $\mathrm{Mg}^{2+}(F=6.83 ; P<0.01)$, and total $\mathrm{S}(F=$ $18.61 ; P<0.0001)$ in plant tissues of 'Apollo Cinnamon'. Salinity had a significant effect on $\mathrm{Na}^{+}(F=15.28 ; P<0.0001), \mathrm{K}^{+}(F=$ 52.62; $P<0.0001)$, total $\mathrm{P}(F=12.84 ; P<$ $0.0001)$, and $\mathrm{Cl}^{-}(F=54.6 ; P<0.0001)$ concentrations found in tissues of 'Apollo Cinnamon'. Type of water composition had no individual effect on any of the mineral concentrations (Fig. 1A-G).

For 'Monaco Rose', water ionic composition and salinity had significant two-way interactions for mineral concentrations of $\mathrm{Ca}^{2+}(F=3.94 ; P<0.05), \mathrm{Mg}^{2+}(F=7.96$; $P<0.001)$, total $\mathrm{P}(F=3.95 ; P<0.05)$, and total $\mathrm{S}(F=29.12 ; P<0.0001)$ in plant tissues of 'Monaco Rose'. Salinity had a significant effect on $\mathrm{Na}^{+}(F=17.8 ; P<0.0001), \mathrm{K}^{+}(F=$
84.94; $P<0.0001)$, and $\mathrm{Cl}^{-}(\mathrm{F}=47.13 ; P<$ $0.0001)$ concentrations found in tissues of 'Monaco Rose'. No mineral concentrations were affected by type of water composition alone (Fig. 2A-G).

Plant growth measurements. Measurements of plant growth showed an overall decrease as salinity increased for both cultivars irrigated with both water compositions (Figs. 3 and 4). Interactions between salinity and ionic water composition were found to significantly affect total shoot height $(F=$ 3.76; $P<0.05)$, stem height $(F=3.10 ; P<$ $0.05)$, basal diameter $(F=3.50 ; P<0.05)$, and total shoot mass $(F=3.16 ; P<0.05)$ of 'Apollo Cinnamon'. Salinity had a significant effect on inflorescence height $(F=10.96 ; P<$ $0.0001)$, cut flower diameter $(F=21.84 ; P<$ $0.0001)$, and cut flower mass $(F=17.19$; $P<0.0001)$ of 'Apollo Cinnamon'. Water composition had no individual effect on growth parameters (Fig. 3A-F). Salinity also had a significant effect on number of days to harvest $(F=17.01 ; P<0.0001 ;$ data not shown) and delayed timing of harvest. The number of days to harvest increased from a mean of $117 \mathrm{~d}$ in the control to $135 \mathrm{~d}$ in the 14 $\mathrm{dS} \cdot \mathrm{m}^{-1}$ treatment for plants grown in CCRW and from a mean of $113 \mathrm{~d}$ in the control to $140 \mathrm{~d}$ in the $14 \mathrm{dS} \cdot \mathrm{m}^{-1}$ treatment for those grown in SWD.

For 'Monaco Rose', interactions between salinity and ionic water composition were found to significantly affect cut flower diameter $(F=3.37 ; P<0.05)$ and total shoot mass $(F=3.17 ; P<0.05)$. Salinity affected total shoot height $(F=58.78 ; P<0.0001)$, stem height $(F=26.07 ; P<0.0001)$, inflorescence height $(F=29.22 ; P<0.0001)$, and cut flower mass $(F=16.01 ; P<0.0001)$. Type of water composition individually affected total shoot height $(F=16.27 ; P<0.001)$ and stem height $(F=12.50 ; P<0.005)$. Basal diameter of stems of 'Monaco Rose' was unaffected by either treatment (Fig. 4A-F). Salinity affected number of days to harvest $(F=7.10$; $P<0.001$; data not shown) and delayed time to harvest. The number of days to harvest increased from a mean of $121 \mathrm{~d}$ in the control to $133 \mathrm{~d}$ in the $14 \mathrm{dS} \cdot \mathrm{m}^{-1}$ treatment for plants grown in CCRW and from a mean of $120 \mathrm{~d}$ in the control to $138 \mathrm{~d}$ in the $14 \mathrm{dS} \cdot \mathrm{m}^{-1}$ treatment for those grown in SWD.

Germination. Salinity had a significant effect on the germination of 'Apollo Cinnamon' $(F=3.26 ; P<0.05)$, but neither water ionic composition $(F=3.32 ; P>0.05)$ nor an interaction between the two $(F=0.79 ; P>$ 0.05 ) had a significant influence on the germination of this cultivar (Fig. 5A). Results of the Bonferroni post hoc test showed that seeds germinated in the control differed from those germinated at a salinity of $14 \mathrm{dS} \cdot \mathrm{m}^{-1}$. For seeds irrigated with SWD, germination ranged from $92 \%$ for those seeds exposed to $14 \mathrm{dS} \cdot \mathrm{m}^{-1}$ to $98 \%$ for seeds in the control. Germination ranged from $95 \%$ for seeds exposed to $14 \mathrm{dS} \cdot \mathrm{m}^{-1}$ to $100 \%$ for seeds in the control when irrigated with CCRW (Fig. 5A).

Similarly, water ionic composition $(F=$ $2.54 ; P>0.05)$, salinity $(F=1.39 ; P>0.05)$, 

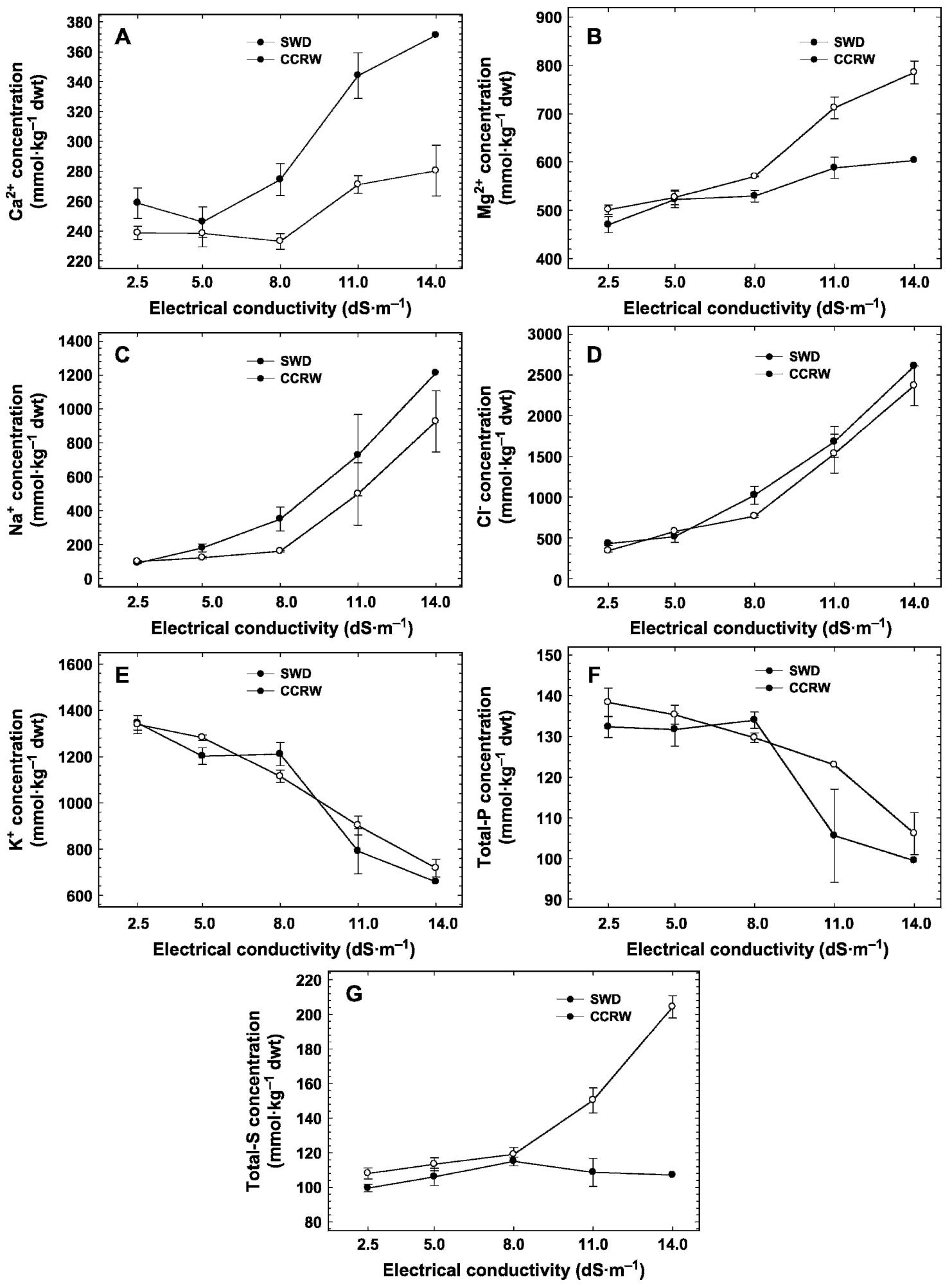

Fig. 1. Concentrations of ions (mean $\pm \mathrm{SE}$ ) in tissues of 'Apollo Cinnamon' from plants irrigated with sea water (SWD) or Colorado River water (CCRW) and five salinity treatments. Ions sampled include: (A) $\mathrm{Ca}^{2+},(\mathbf{B}) \mathrm{Mg}^{2+},(\mathbf{C}) \mathrm{Na}^{+},(\mathbf{D}) \mathrm{Cl}^{-},(\mathbf{E}) \mathrm{K}^{+},(\mathbf{F})$ total $\mathrm{P}$, and (G) total S.

and their interaction $(F=1.22 ; P>0.05)$ had no effect on germination of seeds of 'Monaco Rose' (Fig. 5B). For seeds irrigated with SWD, germination ranged from $92 \%$ for those seeds exposed to $8 \mathrm{dS} \cdot \mathrm{m}^{-1}$ and $14 \mathrm{dS} \cdot \mathrm{m}^{-1}$ to $99 \%$ for seeds in the control. Germination ranged from $93 \%$ for seeds exposed to 8 $\mathrm{dS} \cdot \mathrm{m}^{-1}$ to $99 \%$ for seeds exposed to $5 \mathrm{dS} \cdot \mathrm{m}^{-1}$ when irrigated with CCRW (Fig. 5B).
Grades. Both cultivars grown in either water composition produced "special" quality snapdragons given a minimum stem length requirement of $91 \mathrm{~cm}$ and a minimum mass requirement of $71 \mathrm{~g}$ (Dole and Wilkins, 1999) (Table 2). 'Apollo Cinnamon' was graded as "special" when grown in conductivities up to $8 \mathrm{dS} \cdot \mathrm{m}^{-1}$ and as "fancy" in 11 to $14 \mathrm{dS} \cdot \mathrm{m}^{-1}$ in CCRW and rated as "fancy" at
$14 \mathrm{dS} / \mathrm{m}$ in SWD. 'Monaco Rose' was graded as "special" when grown in all conductivities and water types tested (Table 2).

\section{Discussion}

An overall increase in $\mathrm{Ca}^{2+}$ concentration was found for both snapdragon cultivars exposed to both water treatments as salinity 

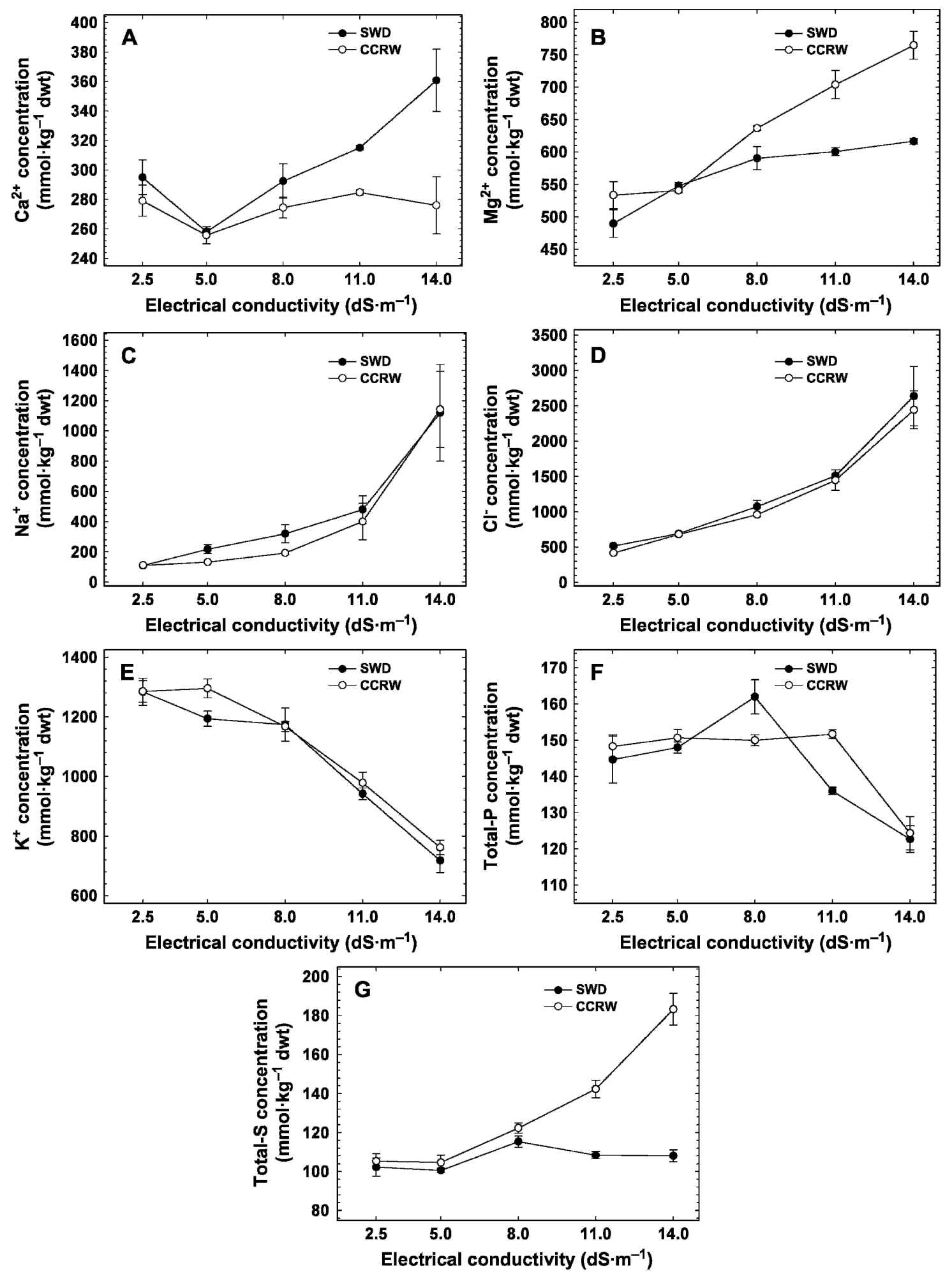

Fig. 2. Concentrations of ions (mean $\pm \mathrm{SE}$ ) in tissues of 'Monaco Rose' from plants irrigated with sea water (SWD) or Colorado River water (CCRW) and five salinity treatments. Ions sampled include: (A) $\mathrm{Ca}^{2+},(\mathbf{B}) \mathrm{Mg}^{2+},(\mathbf{C}) \mathrm{Na}^{+},(\mathbf{D}) \mathrm{Cl}^{-},(\mathbf{E}) \mathrm{K}^{+}$, (F) total $\mathrm{P}$, and (G) total S.

increased. Typically, $\mathrm{Ca}^{2+}$ decreases as salinity increases because cellular membranes become unable to distinguish between $\mathrm{Na}^{+}$ and $\mathrm{Ca}^{2+}$ as salinity increases and so lose their ability to uptake $\mathrm{Ca}^{2+}$ preferentially (Suarez and Grieve, 1988). Our findings differ from previous investigations of floral crops and other vegetable crops in which $\mathrm{Ca}^{2+}$ was found to decrease as salinity (as a result of
$\mathrm{Na}^{+}$) increased. Carter et al. (2005a) found that $\mathrm{Ca}^{2+}$ concentrations in two floral cultivars of Celosia argentea ('Chief Gold' and 'Chief Rose') decreased when exposed to salt solutions of SWD and CCRW (labeled as Imperial/Coachella Valleys in their article) as salinity increased from $2.5 \mathrm{dS} \cdot \mathrm{m}^{-1}$ to 12 $\mathrm{dS} \cdot \mathrm{m}^{-1}$. Similar results were also found by Carter et al. (2005b) when Limonium perezii
('Blue Seas') was exposed to water ionic compositions mimicking 1) concentrations of the Colorado River and 2) saline drainage effluents present in the San Joaquin Valley of California. In their investigation, salinity ranged from 2 to $20 \mathrm{dS} \cdot \mathrm{m}^{-1}$ and plant tissue concentrations of $\mathrm{Ca}^{2+}$ showed an overall decrease as salinity increased. Calcium concentrations in leafy vegetables (kale, tatsoi, 

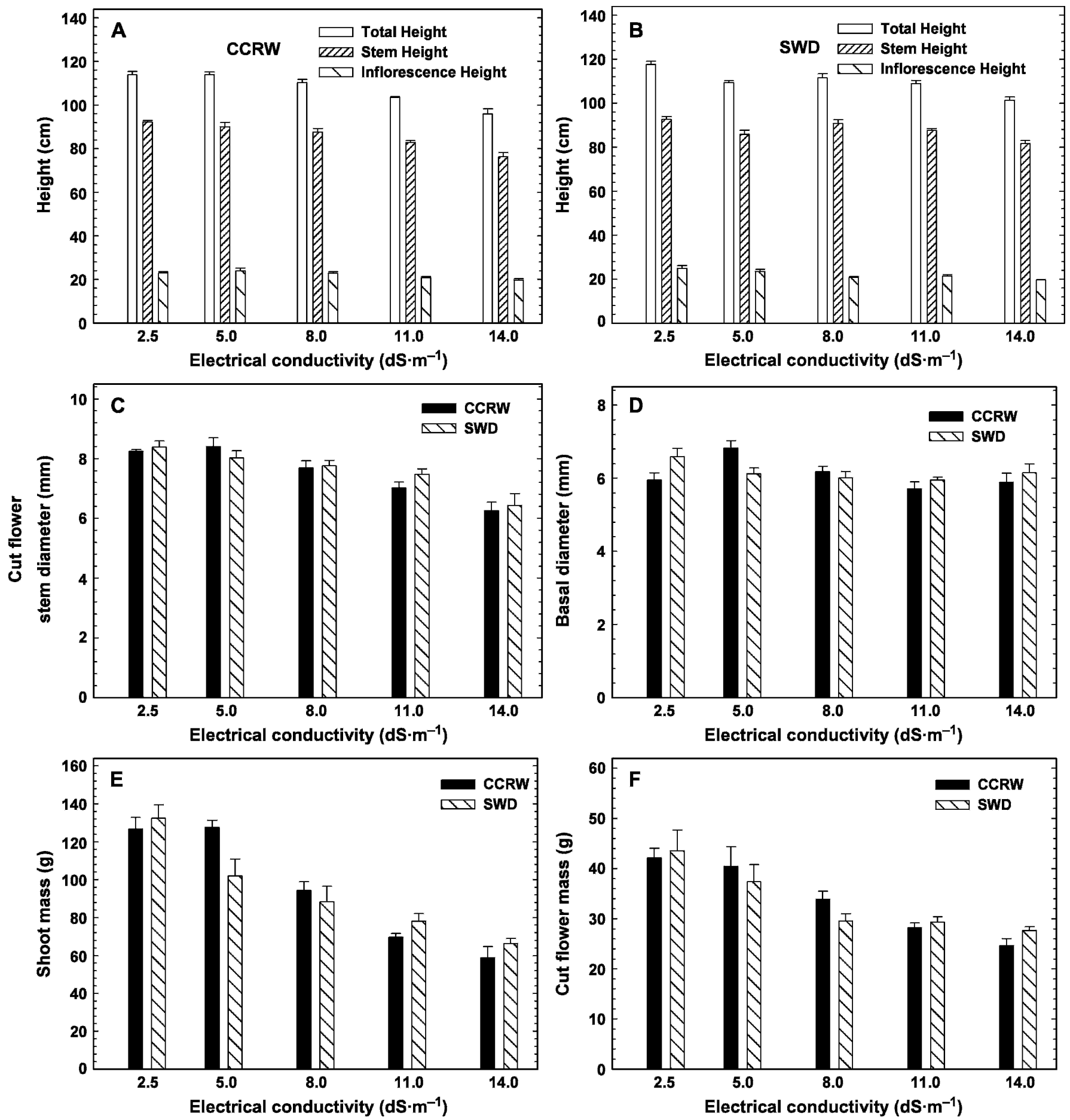

Fig. 3. Plant growth measurements (mean \pm SE) of 'Apollo Cinnamon' irrigated with sea water (SWD) or Colorado River water (CCRW) and five salinity treatments. Measurements include total plant height, stem height, and inflorescence height of plants irrigated in (A) Colorado River water (CCRW) and (B) sea water (SWD). Other measurements include (C) cut flower stem diameter, (D) basal diameter, (E) plant mass, and (F) cut flower mass.

pac choi, endive, spinach, Swiss chard) irrigated with sodium sulfate-dominated waters decreased consistently and significantly as salinity increased from 3 to $23 \mathrm{dS} \cdot \mathrm{m}^{-1}$ (Grieve et al., 2001). However, in an investigation of salt-tolerant forages irrigated with saline drainage effluents of the San Joaquin Valley, Grieve et al. (2004) found that $\mathrm{Ca}^{2+}$ concentrations in shoots of Agropyron elongatum (tall wheatgrass cv. Jose), Sporobolus airoides (alkali sacaton), Paspalum vaginatum (paspalum cvs. 299042 and Polo), and
Cynodon dactylon (bermudagrass cv. Tifton) grown in 15 and $25 \mathrm{dS} \cdot \mathrm{m}^{-1}$ increased over the course of the growing period. Many of these species also showed little difference in $\mathrm{Ca}^{2+}$ concentration for those plants irrigated at the two different salinities, although the tendency was for $\mathrm{Ca}^{2+}$ concentrations to be higher in those plants exposed to $15 \mathrm{dS} \cdot \mathrm{m}^{-1}$ irrigation water when compared with those grown in $25 \mathrm{dS} \cdot \mathrm{m}^{-1}$. In our investigation, the uptake of $\mathrm{Ca}^{2+}$ in snapdragons was unaffected by increasing $\mathrm{Na}^{+}$up to $14 \mathrm{dS} \cdot \mathrm{m}^{-1}(98.7 \mathrm{~mm})$.
Additionally, we found that $\mathrm{Ca}^{2+}$ concentrations were higher in plant tissues irrigated with SWD when compared with those irrigated with CCRW water for both cultivars, although $\mathrm{Ca}^{2+}$ concentrations were higher in CCRW than in SWD. This may be explained by the concentration of $\mathrm{Mg}^{2+}$ and the ratio of $\mathrm{Mg}^{2+}: \mathrm{Ca}^{2+}$ in the irrigation water. Typically, calcium is reported to be strongly competitive with $\mathrm{Mg}^{2+}$ and is favored at binding sites on the plasma membrane because $\mathrm{Mg}^{2+}$ is highly hydrated (Marschner, 1995). Unlike 

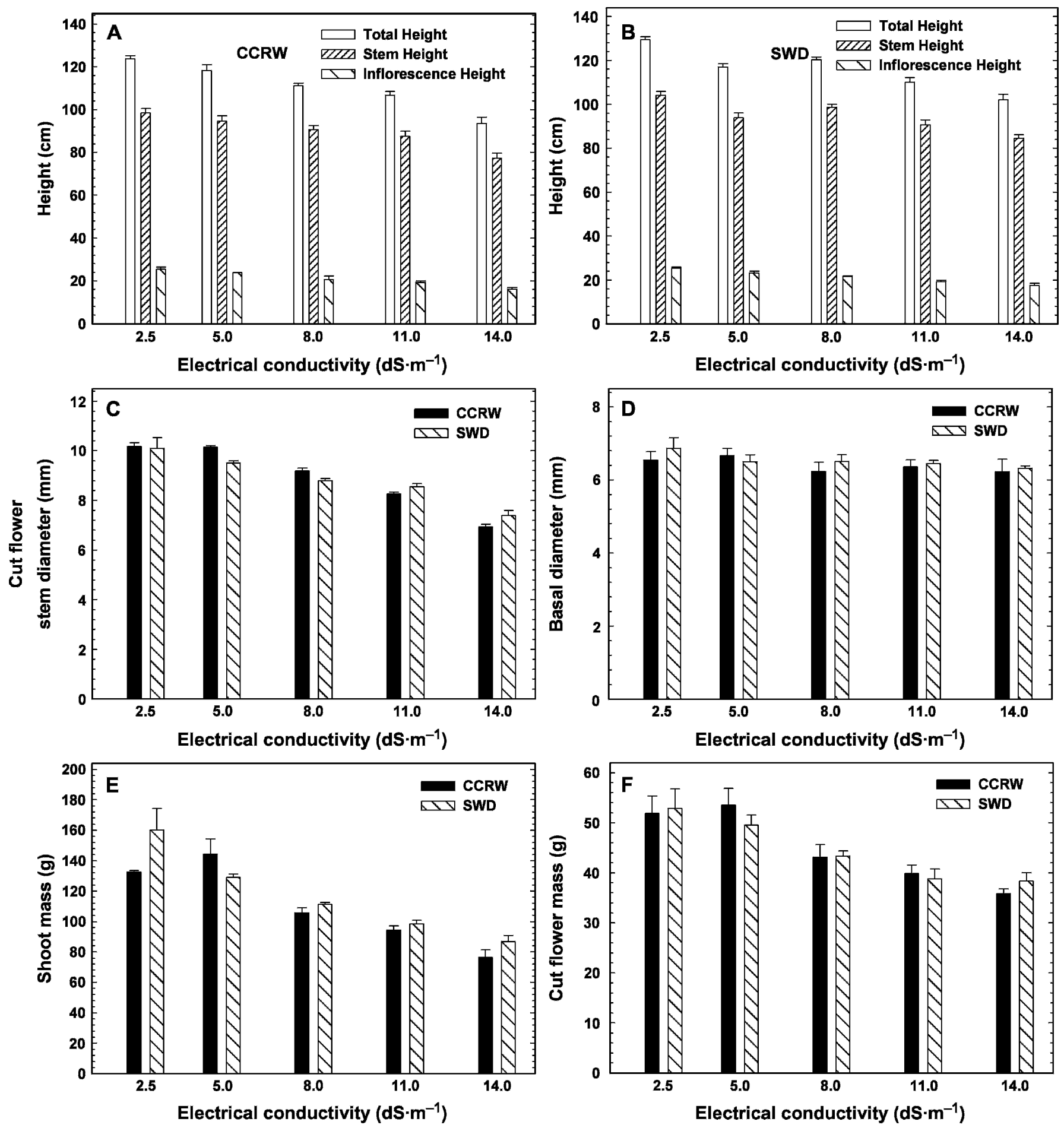

Fig. 4. Plant growth measurements (mean $\pm \mathrm{sE}$ ) of 'Monaco Rose' irrigated with sea water (SWD) or Colorado River water (CCRW) and five salinity treatments. Measurements include total plant height, stem height, and inflorescence height of plants irrigated in (A) Colorado River water (CCRW) and (B) sea water (SWD). Other measurements include (C) cut flower stem diameter, (D) basal diameter, (E) plant mass, and (F) cut flower mass.

previous investigations, our results indicate that $\mathrm{Mg}^{2+}$ is competitive with $\mathrm{Ca}^{2+}$ in snapdragons and $\mathrm{Mg}^{2+}$ concentrations in plant tissues show a direct relationship to the increase of $\mathrm{Mg}^{2+}$ in substrate water. The ratio of $\mathrm{Mg}^{2+}: \mathrm{Ca}^{2+}$ in CCRW ranged from $1.3: 1$ in the control to $1.7: 1$ at the highest salinity. When increases in $\mathrm{Mg}^{2+}$ were found in substrate solutions, which may have been enough to offset any competition from $\mathrm{Ca}^{2+}$ (especially in CCRW), an increase in $\mathrm{Mg}^{2+}$ in plant tissues was also found. There is also a corresponding reversal in $\mathrm{Ca}^{2+}$ uptake in plants irrigated with $\mathrm{CCRW}$; as $\mathrm{Mg}^{2+}$ increases in plant tissues, $\mathrm{Ca}^{2+}$ also increases, but not at concentrations found for $\mathrm{Mg}^{2+}$ for plants irrigated with CCRW. Likewise, in plants irrigated with SWD in which the $\mathrm{Mg}^{2+}$ : $\mathrm{Ca}^{2+}$ ratio is $1: 1$, more $\mathrm{Ca}^{2+}$ accumulates in plant tissues. The corresponding levels of $\mathrm{Mg}^{2+}$ also increase, but not as high as the concentrations found for $\mathrm{Ca}^{2+}$.
Increases in $\mathrm{Na}^{+}$and $\mathrm{Cl}^{-}$in plant tissues can be directly tied to the increasing $\mathrm{NaCl}$ concentrations of the irrigation water. The amount of $\mathrm{NaCl}$ in SWD was slightly higher than that found in CCRW. For both cultivars, we found that the amount of $\mathrm{Na}^{+}$and $\mathrm{Cl}^{-}$in shoots was slightly higher in plants irrigated with SWD when compared with those irrigated with CCRW. Similar results were found for two cultivars of Celosia argentea exposed to SWD and CCRW (Carter et al., 

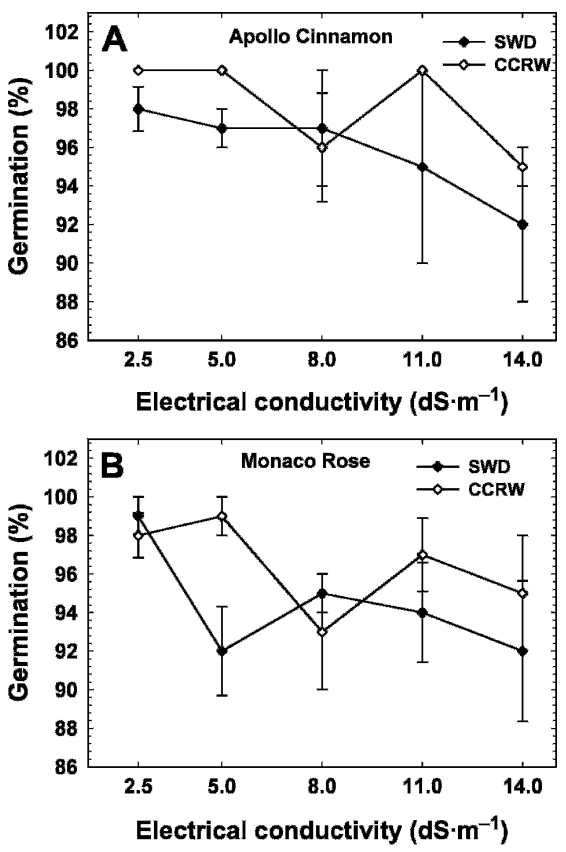

Fig. 5. Percent germination (mean $\pm \mathrm{SE}$ ) of seeds of (A) 'Apollo Cinnamon' and (B) 'Monaco Rose' exposed to Colorado River water (CCRW) or sea water (SWD) and five salinities.

Table 2. Quality grades (Dole and Wilkins, 1999) of two cultivars of snapdragon produced under increasing salinity $\left(\mathrm{EC}=\mathrm{dS} \cdot \mathrm{m}^{-1}\right)$ and two different irrigation water types.

\begin{tabular}{|c|c|c|c|c|c|}
\hline \multicolumn{3}{|c|}{ Apollo Cinnamon } & \multicolumn{3}{|c|}{ Monaco Rose } \\
\hline Water & $\mathrm{EC}$ & $\overline{\text { Grade }^{z}}$ & Water & $\mathrm{EC}$ & $\overline{\text { Grade }}$ \\
\hline \multirow[t]{5}{*}{$\overline{\mathrm{CCRW}}$} & 2.5 & Special & CCRW & 2.5 & Special $^{\mathrm{y}}$ \\
\hline & 5 & Special & & 5 & Special $^{\mathrm{y}}$ \\
\hline & 8 & Special & & 8 & Special \\
\hline & 11 & Fancy & & 11 & Special \\
\hline & 14 & Fancy & & 14 & Special \\
\hline \multirow[t]{5}{*}{ SWD } & 2.5 & Special & SWD & 2.5 & Special ${ }^{\mathrm{y}}$ \\
\hline & 5 & Special & & 5 & Special ${ }^{\mathrm{y}}$ \\
\hline & 8 & Special & & 8 & Special \\
\hline & 11 & Special & & 11 & Special \\
\hline & 14 & Fancy & & 14 & Special \\
\hline
\end{tabular}

${ }^{\mathrm{z}}$ Special grade is based on a minimum stem length of $91 \mathrm{~cm}$ when the inflorescence is included in this measurement and a minimum mass of $71 \mathrm{~g}$.

y'Monaco Rose' plants grown in either water composition up to $5 \mathrm{dS} \cdot \mathrm{m}^{-1}$ were above the maximum stem weight of $113 \mathrm{~g}$.

$\mathrm{EC}=$ electrical conductivity; CCRW = concentrations of Colorado River water; SWD = dilutions of sea water.

2005a). In their investigation, plants exposed to SWD contained higher amounts of $\mathrm{Na}^{+}$and $\mathrm{Cl}^{-}$in plant tissues when compared with those grown in water from the CCRW where substrate $\mathrm{NaCl}$ was comparatively less. Carter et al. (2005b) also showed that concentrations of $\mathrm{Na}^{+}$and $\mathrm{Cl}^{-}$in plant tissues of Limonium perezii were directly influenced by the $\mathrm{NaCl}$ concentration of the substrate solutions.

Potassium decreased as overall salinity increased. This can be attributed to the increase of $\mathrm{Na}^{+}$in substrate solutions given that $\mathrm{K}^{+}$was maintained at $5 \mathrm{~mm}$ in both substrate solutions. Sodium inhibits the uptake of $\mathrm{K}^{+}$ by interfering with $\mathrm{K}^{+}$ion channels in the plasma membrane of the root and also competes with $\mathrm{K}^{+}$for binding sites, especially under high $\mathrm{Na}^{+}$: $\mathrm{K}^{+}$ratios (Maathuis and Amtmann, 1999; Tester and Davenport, 2003). There was a somewhat higher amount of $\mathrm{K}^{+}$in plants irrigated with CCRW as opposed to those irrigated with SWD for both cultivars. This can be attributed to the lower concentrations of $\mathrm{Na}^{+}$in the CCRW irrigation water. Typically, nutrient deficiencies can occur when plants are exposed to high amounts of sodium, but we saw no visual evidence of potassium deficiency or sodium toxicity in the plants tested, even at the highest salinities. Typical indicators of potassium deficiency would include interveinal chlorosis along the margins appearing as a yellow to tan color that eventually turn brown (Warncke and Krauskopf, 1998). If sodium is also present in the leaf, entire leaves can turn brown (Ulrich and Ohki, 1966). Sodium toxicity causes necroses along the margins, tips, or in interveinal areas (Lunt, 1966).

Total phosphorus declined in both saline water treatments as salinity increased for both cultivars. Grattan and Grieve (1999) reported that the interaction between salinity and phosphorus is dependent on plant species, age of the plant, composition of the substrate irrigation water and salinity level, and the amount of phosphorus in the substrate. Decline in total phosphorus has been linked to the increase of calcium in substrate solutions (Sharpley et al., 1992). High amounts of calcium in substrate solutions result in the precipitation of calcium phosphate when $\mathrm{P}$ is added to the system (Sharpley et al., 1992). Conflicting results of $\mathrm{P}$ uptake were reported by Champagnol (1979) who found that corn, sesame, and sorghum increased phosphorus concentrations in plant material, whereas barley, onion, and tomato decreased in concentrations of phosphorus as substrate salinity increased. Carrot, cabbage, millet, and wheat maintained similar $\mathrm{P}$ levels across increasing salinity. In this investigation, we would have expected $\mathrm{P}$ uptake to be greater in plants irrigated with SWD because the amount of calcium is less in this irrigation water than was present in CCRW, so it would have been more likely that the amount of available phosphorus would have precipitated as calcium phosphate in CCRW, making it unavailable for the plant. Throughout this investigation, uptake of phosphorus tended to be higher in plants irrigated with CCRW despite higher concentrations of calcium in this substrate solution when compared with that of SWD. It is difficult to compare these findings with other investigations of total $\mathrm{P}$ uptake in floral crops. Carter et al. (2005a, 2005b) found that total $P$ uptake fluctuated in Celosia argentea and Limonium perezii, respectively, as substrate salinity increased when plants were irrigated with two different substrate solutions with varying amounts of calcium.

Total S concentrations increased in plants irrigated with CCRW and tended to remain constant in those irrigated with SWD as salinity increased. The increase in uptake of total $\mathrm{S}$ can be attributed to the increase in $\mathrm{SO}_{4}{ }^{-2}$ in the CCRW solution when compared with that of SWD. Plants also select for $\mathrm{SO}_{4}{ }^{-2}$ preferentially over $\mathrm{Cl}^{-}$(White and Broadley, 2001). Our results indicate that snapdragons continued to accumulate $\mathrm{Cl}^{-}$as well as total S as salinity increased for both cultivars irrigated with CCRW. No preferential uptake of either ion was evident. For plants treated with SWD, $\mathrm{Cl}^{-}$concentrations continue to increase in plant tissues and total $\mathrm{S}$ concentrations only showed a slight increase. This relatively small increase in $\mathrm{SO}_{4}{ }^{-2}$ is explained by the small amount of $\mathrm{SO}_{4}^{-2}$ present in the irrigation water. Our findings differ from previous investigations in which selectivity for $\mathrm{SO}_{4}^{-2}$ over $\mathrm{Cl}^{-}$was evident in cut flowers of Celosia argentea and Limonium perezil under increasingly saline conditions (Carter et al., 2005a, 2005b). In these instances, plants treated with irrigation water containing higher amounts of sulfate resulted in higher concentrations of total $\mathrm{S}$ in plant tissues as $\mathrm{Cl}^{-}$leveled off or remained constant as salinity increased.

Little information is provided in the literature regarding growth of snapdragons under saline conditions. Monk and Peterson (1961) reported that snapdragons can survive in salt concentrations up to $60 \mathrm{meq} \cdot \mathrm{L}$ in a sodium and calcium chloride solution, but did not report stem lengths or quality of the flowers. Our results show that stem height alone (not including the inflorescence) was well above $76 \mathrm{~cm}$ for both cultivars irrigated with both water solutions up to $14 \mathrm{dS} \cdot \mathrm{m}^{-1}$. Inflorescence height showed only slight decreases in height as salinity decreased and still produced compact flowering stalks with numerous flowers under the highest salinities. These findings become important when grading the quality of snapdragons. The Society of American Florists provides specifications for four grades of snapdragons based on stem weight, number of open flowers, and minimum stem length. From lowest to highest grade, these grades are labeled as: "first," "extra," "fancy," and "special" (Dole and Wilkins, 1999). In summary, 'Apollo Cinnamon' was graded as "special" when grown in conductivities up to $8 \mathrm{dS} \cdot \mathrm{m}^{-1}$ and as "fancy" in 11 to $14 \mathrm{dS} \cdot \mathrm{m}^{-1}$ depending on stem length, weight, and cultivar. 'Monaco Rose' was graded as "special" when grown in all conductivities and water types tested. Salinity functions as a mechanism to reduce overall mass, thereby promoting and improving the quality ranking of the cut flower.

Additionally, stem diameters and basal diameters remained thick, but overall shoot mass and cut flower mass declined. This can be attributed to a reduction in stem length and slight decreases in stem and basal diameter. Similar phenotypic findings have been shown for cut flowers of Limonium perezii and Celosia argentea. Carter et al. (2005b) showed that conductivity levels up to 6 $\mathrm{dS} \cdot \mathrm{m}^{-1}$ using irrigation solutions higher in sulfate salts were best to produce cut flowers of $L$. perezii with high-quality stems when 
compared with irrigation water of the Imperial and Coachella Valleys. Carter et al. (2005a) reported that $C$. argentea 'Chief Gold' would produce high-quality stems even at the highest salinities of $12 \mathrm{dS} \cdot \mathrm{m}^{-1}$ and 'Chief Rose' at salinties of $10 \mathrm{dS} \cdot \mathrm{m}^{-1}$ when irrigated with water compositions similar to the Imperial and Coachella Valleys of California and up to $8 \mathrm{dS} \cdot \mathrm{m}^{-1}$ when irrigated with water compositions similar to SWD. Overall, A. majus could easily withstand shipping for distant markets given their long stems. It would be interesting to continue this investigation with salinities above $14 \mathrm{dS} \cdot \mathrm{m}^{-1}$ to determine further affects of salinity on the growth of Antirrhinum majus.

Germination for seeds of both cultivars remained higher than $92 \%$ when irrigated in both ionic water solutions. Our findings show that cut flowers of snapdragon can be produced by direct seeding under highly saline conditions given that there was no statistically significant difference between treatments and given the overall high rate of germination. Typically, the germination stage of development is the most sensitive to increases in salinity. Under saline conditions, seeds of many species, halophytes included, become dormant until saline conditions are alleviated. Seeds of snapdragons are seemingly unaffected when exposed to salinities up to $14 \mathrm{dS} \cdot \mathrm{m}^{-1}$ and remain nondormant. We recognize the possibility that seedling emergence may not be achieved for this same cultivar although radicle emergence was successful under the salinities we tested. However, in this investigation, we observed greening cotyledons emerging from their seedcoats in the Petri dishes in numbers nearly identical to the number of seeds whose radicles emerged.

'Monaco Rose' and 'Apollo Cinnamon' cultivars of snapdragon can be produced from seed when exposed to salinities up to $14 \mathrm{dS} \cdot \mathrm{m}^{-1}$ using both SWD and CCRW ionic solutions for irrigation. Both cut flower cultivars can also produce high-quality stems commercially under saline conditions up to at least $14 \mathrm{dS} \cdot \mathrm{m}^{-1}$ based on the standard rating system developed specifically for snapdragon by the Society of American Florists. Quality was maintained using either irrigation water type, indicating that these cultivars can be grown in coastal areas where chloride is the dominant salt or in areas irrigated by CCRW where both chloride and sulfate salts predominate. As salinity in- creases, $\mathrm{Ca}^{2+}, \mathrm{Mg}^{2+}, \mathrm{Na}^{+}, \mathrm{Cl}^{-}$, and total $\mathrm{S}$ increase in plant tissues, whereas $\mathrm{K}^{+}$and total $\mathrm{P}$ decrease in plant tissues for both cultivars in both irrigation water. The uptake of these nutrients is related to their interactions within the substrate solutions and their ability to compete for uptake at the site of the root membranes.

\section{Literature Cited}

Adam, P. 1990. Saltmarsh ecology. Cambridge University Press, Cambridge, UK.

Armitage, A.M. 1993. Specialty cut flowers. Varsity Press/Timber Press, Portland, OR.

Ayers, R.S. and D.W. Westcot. 1985. Water quality for agriculture. FAO Irrigation and Drainage Paper 29. Food and Agricultura Organization of the United Nations, Rome, Italy.

Carter, C.T. and C.M. Grieve. 2006. Salt tolerance of floriculture crops, p. 279-288. In: Khan, M.A. and D.J. Weber (eds.). Ecophysiology of high salinity tolerant plants. Chapter 19. Springer, The Netherlands.

Carter, C.T., C.M. Grieve, J.A. Poss, and D.L. Suarez. 2005a. Production and ion uptake of Celosia argentea irrigated with saline wastewaters. Sci. Hort. 106:381-394.

Carter, C.T., C.M. Grieve, and J.A. Poss. 2005b. Salinity effects on emergence, survival, and ion accumulation of Limonium perezii. J. Plant Nutr. 28:1243-1257.

Census of Horticultural Specialties. 1998. Cut flowers sold by state, p. 167-181. Aug. 2003. $<\mathrm{http} / / /$ www.nass.usda.gov/census/census97/ horticulture/horticulture.htm>.

Champagnol, F. 1979. Relationship between phosphate nutrition of plants and salt toxicity. Phosphorus Agr. 76:35-44.

Corr, B. and L. Laughner. 1998. Antirrhinum (snapdragon), p. 356-367. In: Ball, V. (ed.). Ball redbook. 16th Ed. Ball Publishing, Batavia, IL.

Dole, J.M. and H.F. Wilkins. 1999. FloriculturePrinciples and species. Prentice Hall, Upper Saddle River, NJ.

Gleason, H.A. and A. Cronquist. 1991. Manual of vascular plants of northeastern United States and adjacent Canada. 2nd Ed. New York Botanical Garden, Bronx, NY.

Grattan, S.R. and C.M. Grieve. 1999. Salinitymineral nutrient relations in horticultural crops. Sci. Hort. 78:127-157.

Greenway, H. and R. Munns. 1980. Mechanisms of salt tolerance in nonhalophytes. Ann. Rev. Plant Phys. 31:149-190.

Grieve, C.M., J.A. Poss, and C. Amrhein. 2006. Response of Matthiola incana to irrigation with saline wastewaters. HortScience 41:119-123.

Grieve, C.M., J.A. Poss, S.R. Grattan, D.L. Suarez, S.E. Benes, and P.H. Robinson. 2004. Evaluation of salt-tolerant forages for sequential water reuse systems. II. Plant-ion relations. Agr. Water Mgt. 70:121-135.
Grieve, C.M., M.C. Shannon, and J.A. Poss. 2001. Mineral nutrition of leafy vegetable crops irrigated with saline drainage water. J. Veg. Crops Prod. 71:37-47.

Hintze, J. 2006. NCSS, PASS, and GESS. Number Cruncher Statistical Systems. Number Cruncher Statistical Systems, Kaysville, UT.

Lunt, O.R. 1966. Sodium, p. 409-432. In: Chapman, H.D. (ed.). Diagnostic criteria for plants and soils. Chapter 27. University of California, Division of Agricultural Sciences, Riverside, CA.

Maathuis, F.J.M. and A. Amtmann. 1999. K ${ }^{+}$ nutrition and $\mathrm{Na}^{+}$toxicity: The basis of cellular $\mathrm{K}^{+} / \mathrm{Na}^{+}$ratios. Ann. Bot. (Lond.) 84:123-133.

Marschner, H. 1995. Mineral nutrition of higher plants. Academic Press, London, UK.

Monk, R. and H.B. Peterson. 1961. Flowers tolerant to salinity. Farm Home Sci. 22:17.

Parsons, L.R. 2000. Water management and water relations of horticultural crops: Introduction to the colloquium. HortScience 35:1035-1036.

Prince and Prince, Inc. 2003. California cut-flower production and industry trends $2003-$ A statewide survey of cut-flower growers for the California Cut Flower Commission (CCFC). Columbus, $\mathrm{OH}$.

SAS Institute. 2001. SAS/STAT software. Version 8.2. SAS Institute, Cary, NC.

Sharpley, A.N., J.J. Meisinger, J.F. Power, and D.L. Suarez. 1992. Root extraction of nutrients associated with long-term soil management, $\mathrm{p}$. 151-217. In: Hatfield, J.L. and B.A. Stewart (eds.). Advances in soil science. Vol. 19. Limitations to plant growth. Springer-Verlag, New York, NY.

Suarez, D.L. and C.M. Grieve. 1988. Predicting cation ratios in corn from saline solution composition. J. Expt. Bot. 39:605-612.

Suarez, D.L. and J. Simunek. 1997. UNSAT CHEM: Unsaturated water and solute transport model with equilibrium and kinetic chemistry. Soil Sci. Soc. Amer. J. 61:1633-1646.

Tester, M. and R. Davenport. 2003. $\mathrm{Na}^{+}$tolerance and $\mathrm{Na}^{+}$transport in higher plants. Ann. Bot. (Lond.) 91:503-527.

Ulrich, A. and K. Ohki. 1966. Potassium, p. 362 393. In: Chapman, H.D. (ed.). Diagnostic criteria for plants and soils. Chapter 24. University of California, Division of Agricultural Sciences, Riverside, CA.

Ungar, I.A. 1991. Ecophysiology of vascular halophytes. CRC Press, Boca Raton, FL.

Waisel, Y. 1989. Screening for salt resistance, p. 143-155. Proceedings of the 21st Colloquium of the International Potash Institute, Bern, Switzerland.

Warncke, D.D. and D.M. Krauskopf. 1998. Plant nutrition, p. 115-126. In: Ball, V. (ed.). Ball redbook. Ball Publishing, Batavia, IL.

White, P.J. and M.R. Broadley. 2001. Chloride in soils and its uptake and movement within the plant: A review. Ann. Bot. (Lond.) 88:967-988. 